Original Paper http://ajol.info/index.php/ijbcs http://indexmedicus.afro.who.int

\title{
Effects of aqueous extract of Viscum album (Linn.) leaf on some biochemical parameters and ovarian morphology of oestradiol valerate-induced polycystic ovarian syndrome rats
}

\author{
Falilat Adeola OSENI ${ }^{*}$, Amadu Kayode SALAU ${ }^{2}$, Nusra Bolatito Afolabi-BALOGUN ${ }^{2}$ \\ and Elizabeth Abidemi BALOGUN ${ }^{3}$
}

\author{
${ }^{1}$ Department of Biochemistry, University of Ilorin, P.M.B 1515, Ilorin, Nigeria. \\ ${ }^{2}$ Department of Biochemistry and Nutrition, Fountain University, Osogbo, Nigeria. \\ ${ }^{3}$ Department of Biochemistry, University of Ilorin, P.M.B 1515, Ilorin, Nigeria. \\ *Corresponding author; E-mail: falilatoseni@yahoo.com; Tel: +2347062653967/ +2349096466732
}

\begin{abstract}
Polycystic Ovarian Syndrome (PCOS) has a worldwide prevalence of 15-20\% in women of reproductive age group and account for $75 \%$ anovulatory infertility cases in them. Aqueous extract of Viscum album leaf was evaluated for its therapeutic effects on oestradiol valerate - induced PCOS rats. Female rats $(176.96 \pm 2.01) \mathrm{g}$ were assigned to groups $\mathrm{A}-\mathrm{G},(\mathrm{n}=10)$ each. Group A (Control) were administered $0.5 \mathrm{ml}$ of distilled water. Groups B, C, D, E, F and G were PCOS-induced with single intramuscular injection of oestradiol - valerate, each group then received $0.5 \mathrm{ml}$ of distilled water, $2.4 \mathrm{mg} / \mathrm{kg}$ body weight of metformin, $10,50,100$ and $200 \mathrm{mg} / \mathrm{kg}$ body weight of the extract respectively for 30 days. Vaginal smear cytology, serum follicle stimulating hormone, luteinising hormone, testosterone, progesterone and polycystic ovarian morphology were assessed. Aqueous extract of Viscum album leaf significantly ( $<0.05)$ reversed PCOS related increased serum concentrations of follicle stimulating hormone and testosterone and decreased concentration of luteinizing hormone towards the control values. Persistent oestrus cells and cystic follicles in the ovaries of PCOS-induced rats were restored towards control. Aqueous extract of Viscum album leaf ameliorated some clinical, biochemical and ovarian features of polycystic ovarian syndrome rats.
\end{abstract}

(C) 2019 International Formulae Group. All rights reserved.

Keywords: Follicle Stimulating Hormone, Testosterone, vaginal smear, antihypertensive, antidiabetic.

\section{INTRODUCTION}

Polycystic Ovarian Syndrome (PCOS) is a heterogeneous endocrine disorder characterised by irregular menses and hyperandrogenaemia with a worldwide prevalence of $15-20 \%$ in women of reproductive age. The PCOS has been reported in 1 out of 6 infertile Nigerian women (Swetha et al., 2015). It poses huge impact on the reproductive health of affected women and account for $75 \%$ anovulatory infertility cases in them. Therefore, there is the urgent need for their care. Management so far has been with drugs (clomiphene and metformin), ovarian drilling and assisted reproduction technology (Min et al., 2012). These are goal specific and require combination therapy in restoring normal menses/ovulation and /or achieving pregnancy. Drug resistance, response failure 
and other adverse effects like gastrointestinal irritation, diarrhoea, cramps, nausea and vomiting, increased flatulence and lactic acidosis (Lipska et al., 2011) as well as complications like ovarian hyper stimulation syndromes (OHSS) and endometriosis from such treatments (Fernandez et al., 2011), necessitated evaluation of medicinal plant such as crude extracts of Mat ricaria chamomilla, Mimosa pudica, Cnestis ferruginea, which were reported to have therapeutic potential on chemically induced PCOS in rats (Zangeneh et al., 2010, Yakubu and Ibiyo, 2013).

Viscum album Linn (mistletoe) (family $=$ Loranthaceae) locally known as Afomo onisanan (Yoruba) Kauchi (Hausa) and Apari (Igbo) in Nigeria is a semi-parasitic plant that grows as epiphyte on deciduous trees (Ihegboro and Ebuehi, 2014), has been used traditionally to manage various ailments like menstrual disorder; amenorrhea and oligomenorrhoea, as well as infertility in females without the scientific evidence. Therefore, there is need to investigate the effect of Viscum album on PCOS induced rat. Previous reports have shown that it contains lectins, viscotoxin alkaloids, phenolics and flavonoids (Vicas et al., 2012). Antidiabetics, antihypertensive and antioxidant potentials of the extract have also been reported (Umoh et al., 2011, Ihegboro and Ebule, 2014) as well as the ability to regulate insulin secretion (Park, 2019). This study was therefore set to evaluate the therapeutic potential of Viscum album leaves, as complementary and alternative therapy of PCOS induced rats with reference to some biochemical parameters and ovarian histology.

\section{MATERIALS AND METHODS Plant material}

Viscum album leaves were collected from one of the host trees (kola nut) at the Osun grove, Osogbo, South-western Nigeria. The plant was identified and authenticated at the Department of Plant Biology, University of Ilorin, Ilorin, Nigeria. Voucher specimen
(UILH/ 001/1210) was deposited in the herbarium.

\section{Experimental animals}

Seventy female albino rats average weight $176.96 \pm 2.01 \mathrm{~g}$ were used for the study. The animals were obtained from the Animal Holding Unit of the Department of Biochemistry, University of Ilorin, Nigeria, housed in plastic cages and kept under standard laboratory conditions (temperature $22.0 \pm 3.0{ }^{0} \mathrm{C}$ photoperiod: $12 \mathrm{~h} / 12 \mathrm{~h}$ light/dark cycle, free access to rat pellets; (Top Feeds Grand Cereals; Premier Feed Mills Co. Ltd, Nigeria) and tap water.

\section{Assay kits, drugs and other chemicals}

Testosterone, progesterone, follicle stimulating hormone and luteinizing hormone assay kits were products of Monobind Inc. Lake Forest, USA. Oestraldiol valerate (Merit Healthcare Pvt Ltd. Mumbai, Indian) and metformin from (SmithKline Beecham Pharmaceuticals, West Susex UK), other chemicals and reagents used were products of Sigma Aldrich Ltd., Buchs, Canada.

\section{Preparation of aqueous extract of Viscum album leaves}

Using $1000 \mathrm{ml}$ of distilled water, water-soluble constituent of air-dried Viscum album leaves was extracted from $200 \mathrm{~g}$ portion of pulverized leaves for 48 hours. The mixture was filtered (125 Whatman No. 1 qualitative circle $125 \mathrm{~mm} \mathrm{Q}$ filter paper) and the filtrate was lyophilized (J9897/2 Lyotrap lyophilizer, LTF Scientific Greenfield, Oldham, UK), to obtain the concentrate, part of which was used for the phytochemical analyses and reconstituted to the required doses of $10,50,100$ and $200 \mathrm{mg} / \mathrm{kg}$ body weight that was administered in this study.

The concentrate was obtained using the equation:

Final weight of the concentrate (g) x 100

Initial weight of the powder (g) 


\section{Phytochemical screening Secondary metabolite}

Aqueous extract of Viscum album leaves was subjected to chemical constituents screening for the presence of alk aloids, tannins, phenolics, flavonoids, glycosides, saponins, anthraquinones, steroids as well as phlobatannins and The detected metabolites were then quantified as described by Chukwuma and Chigozie (2016).

\section{Elemental analysis}

The x-ray fluorescence (XRF) spectroscopic method described by Ray et al. (2004) was used for the quantification of $\mathrm{K}$, $\mathrm{Ca}, \mathrm{Cr}, \mathrm{Mn}, \mathrm{Cu}, \mathrm{Zn}, \mathrm{Se}$ and $\mathrm{Fe}$ in $V$. album leaves.

\section{Induction and confirmation of PCOS}

Single intra muscular injection of 2$\mathrm{mg} / \mathrm{kg}$-body weight of oestradiol - valerate (EV) in $0.2 \mathrm{ml}$ olive oil was administered to all experimental animals (Zangeneh et al., 2010). Induction of PCOS was confirmed by microscopic monitoring of changes in predominant cell type in vaginal smears during oestrous cycle phases (Marcondes et al., 2002).

\section{Animal grouping and administration of extract}

For evaluation of therapeutic potentials, five experimental rats each with oestradiol valerate-induced PCOS (evidence of irregular oestrous cycle) assigned to; group $B$ received $0.5 \mathrm{ml}$ of distilled water, group $\mathrm{C}$ were treated with $2.4 \mathrm{mg} / \mathrm{kg}$ body weight of metformin while the groups D, E, F and G received orally $10,50,100$ and $200 \mathrm{mg} / \mathrm{kg}$ body weight of the crude extract of aqueous Viscum album respectively, for 30 days. The control rats in group A did not receive oestradiol valerate and, were administered 0.5 $\mathrm{ml}$ of distilled water. Twenty-four hours after the last dose, the rats were anesthetized using diethyl ether, sacrificed and the venous blood sample was collected in plain sample bottles.
Preparation of serum sample and ovary for histological examination

Serum sample was obtained from $5 \mathrm{ml}$ venous blood collected, prepared as described by Yakubu et al. (2008) and stored frozen at $20{ }^{\circ} \mathrm{C}$ until used for the determination of reproductive hormones. The rats were quickly sectioned, ovaries removed and fixed in $10 \%$ formalin for 24 hours. This is then embedded in paraffin and sectioned at $5 \mu \mathrm{m}$ thickness. The thin sections were stained with hematoxylin and eosin (H \& E) and examined under light microscopy for qualitative and quantitative analysis of follicular growth (Michael and Wojciech, 2016).

\section{Determination of reproductive hormones}

Serum concentrations of follicle stimulating hormone, luteinizing hormone, testosterone and progesterone were determined using the enzyme immunoassay kit, which adopted the principle of Burtis and Ashwood (2001).

\section{Data analysis}

Data was analysed using Statistical Package for Social Sciences, version 21.0 (SPSS Inc., Chicago, USA). Values were expressed as mean \pm SEM of five determinations. Differences between means were analysed by one-way Analysis of Variance (ANOVA) followed by Duncan's Multiple Range Test for multiple comparisons. Statistically significant differences between the means were determined at $\mathrm{P}<0.05$.

\section{RESULTS}

Aqueous extract of Viscum album leaves

A $54.8 \mathrm{~g}$ of the concentrate that corresponds to $27.40 \%$ yield was obtained.

Chemical profile of aqueous extract of Viscum album leaves

Aqueous extracts of Viscum album leaves contained cardiac glycosides, saponins, alkaloids, tannins, phenols, and flavonoids, potassium, calcium, chromium, manganese, iron, copper, zinc, selenium (Table1 and 2). Cardiac glycosides and Potassium has the 
highest composition $(4.03 \pm 0.40$ and $27.06 \pm$ $0.27 ; \mathrm{mg} / \mathrm{ml}$ (Table 1 ).

\section{Vaginal smear}

Vagina smear cytology of the oestradiol valerate-treated rats produced cornified cells (Figure 1b) while that of distilled water-treated animals showed combination of epithelial and cornified cells (Figure 1a). Administration of 50, 100 and the $200 \mathrm{mg} / \mathrm{kg}$ body weight of the extract produced leukocyte cells, similar but reduced to that of the oestradiol valerate-treated rats that received metformin (Figure 1d and 1c)

\section{Serum reproductive hormones}

Serum concentrations of follicle stimulating hormone and testosterone were significantly $(\mathrm{p}<0.05)$ increased $(17.48 \%$ and $24.74 \%$ ), whereas the luteinizing hormone was significantly $(\mathrm{p}<0.05)$ reduced by $71.10 \%$ in the oestradiol valerate-induced PCOS rats as compared with the distilled water-treated controls. Administration of aqueous extract of $V$. album leaves at 10 and $100 \mathrm{mg} / \mathrm{kg}$ body weight of the extract significantly $(\mathrm{p}<0.05)$ reduced the follicle stimulating hormone (Table 3). The luteinizing hormone that was significantly $(\mathrm{p}$ $<0.05)$ decreased in the PCOS induced animals was reversed by the extract at 10,50 and $100 \mathrm{mg} / \mathrm{kg}$ body weight, the reversal in the FSH and the LH was comparable with induced rats treated with metformin (Table 3 ). Similarly, 50, 100 and the $200 \mathrm{mg} / \mathrm{kg}$ body weight of the extract significantly $(\mathrm{p}<0.05)$ reduced the concentration of serum testosterone toward the level comparable with rats that received metformin and the control animals administered distilled water (Table 3 ). However, progesterone level was not significantly $(p>0.05)$ altered by all the various treatments in this study (Table 3 ).

\section{Ovarian morphology}

Atretic polycystic follicles (Figure $2 b$ ) were observed in the ovaries of the OVtreated rats whereas the ovaries of the control rats showed healthy developing follicles (Figure 2a). Administration of aqueous extract of $V$. album leaves at 10,100 and $200 \mathrm{mg} / \mathrm{kg}$ body weight corrected the atretic polycystic ovaries induced by OV that reduces the cysts, reverse toward normal architecture of the ovary and oviduct and with ovary producing healthy follicles at different stages of development (Figure 2d, 2f and 2g). Ovaries of the OV- treated rats administered $50 \mathrm{mg} / \mathrm{kg}$ body weight of the extract had necrotic cystic cavities (Figure 2e), similar to necrotizing inflammation produced by the metformin treatment (Figure 2c).

Table 1: Secondary metabolite constituents of aqueous extract of Viscum album leaves.

\begin{tabular}{lc}
\hline Secondary metabolites & Concentration $(\mathbf{m g} / \mathbf{m l})$ \\
\hline Cardiac glycoside & $4.03 \pm 0.40$ \\
Saponins & $1.50 \pm 0.10$ \\
Alkaloids & $0.88 \pm 0.02$ \\
Phenols & $0.04 \pm 0.00$ \\
Tannins & $0.41 \pm 0.05$ \\
Flavonoids & $0.04 \pm 0.00$ \\
Phlobatannins & Not detected \\
Steroids & Not detected \\
Terpenes & Not detected \\
\hline
\end{tabular}

Values are mean \pm SEM of 4 determinations. 
Table 2: Elemental constituents of Aqueous Extract of Viscum album leaves.

\begin{tabular}{lc}
\hline Elements & Quantity $(\mathbf{m g} / \mathbf{m l})$ \\
\hline Potassium & $27.06 \pm 0.27$ \\
Calcium & $23.17 \pm 0.27$ \\
Chromium & $0.85 \pm 0.10$ \\
Manganese & $1.29 \pm 0.03$ \\
Iron & $9.42 \pm 0.24$ \\
Copper & $2.23 \pm 0.09$ \\
Zinc & $1.99 \pm 0.08$ \\
Selenium & $0.29 \pm 0.03$ \\
\hline
\end{tabular}

Values are mean \pm SEM of 4 determinations.
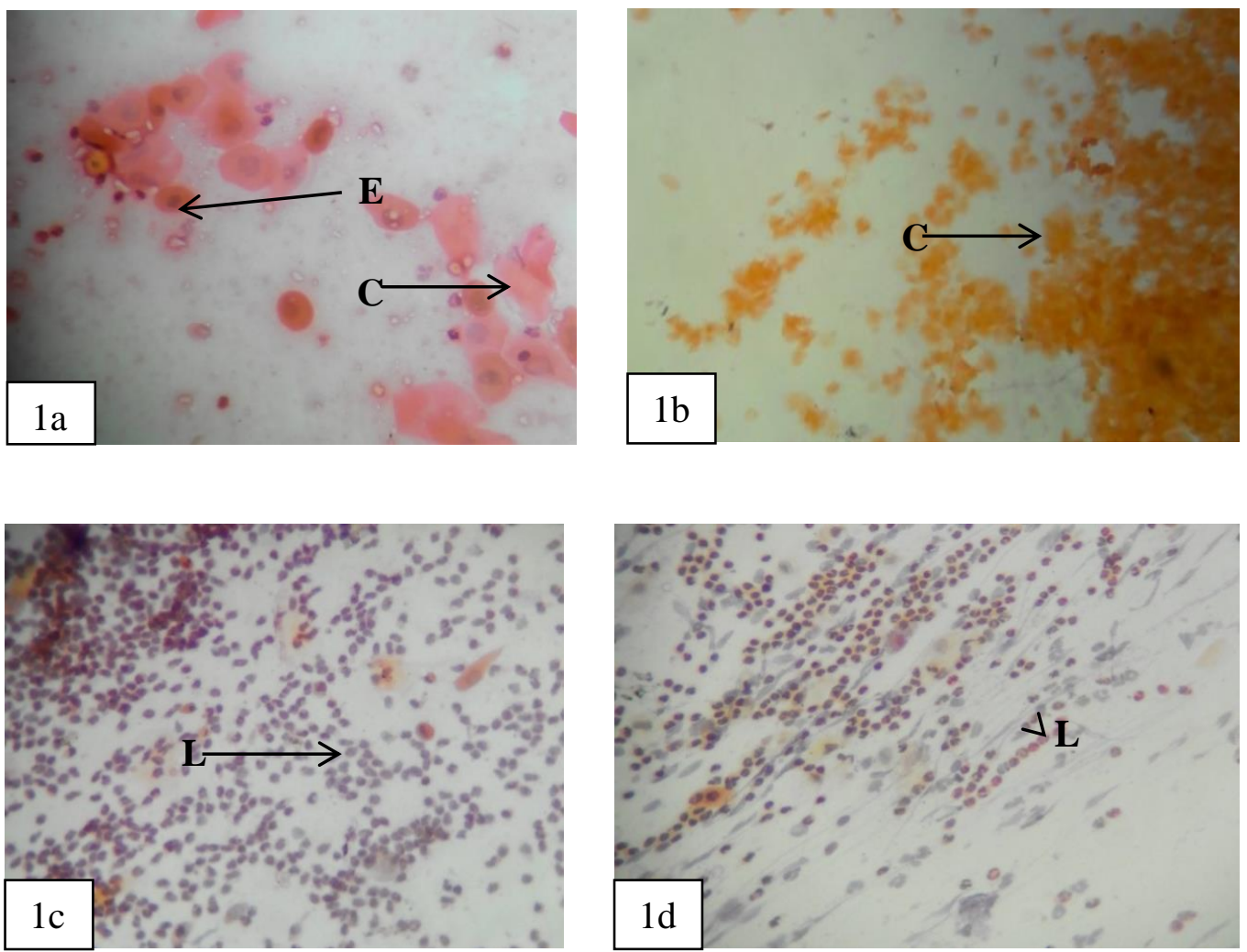

Figure 1: Vaginal Smear Cytology following administration of extract of Viscum album at different concentration.

Figure 1a: Photomicrograph of vaginal smear of the distilled water-treated (control) rat (x100; methyl orange stain. $\mathrm{E}=$ Epithelial cells, $\mathrm{C}=$ Cornified cells).

Figure 1b: Photomicrograph of vaginal smear of $2 \mathrm{mg} / \mathrm{kg}$ body weight oestradiol valerate-treated rat (x100; methyl orange stain. $\mathrm{C}=$ Cornified cells).

Figure 1c: Photomicrograph of vaginal smear of rat administered $2.4 \mathrm{mg} / \mathrm{kg}$ body weight of metformin (x100; methyl blue stain. L= Leukocyte cells).

Figure 1d: Photomicrograph of vaginal smear of rat administered $50 \mathrm{mg} / \mathrm{kg}$ body weight aqueous extract of $V$. album leaves (x100; methyl blue stain. L= Leukocyte cells). 
Table 3: Serum reproductive hormone concentrations of the oestradiol valerate-treated rats after administration of aqueous extract of $\mathrm{V}$. album leaves for 30 days.

\begin{tabular}{|c|c|c|c|c|}
\hline Group & $\begin{array}{l}\text { FSH } \\
(\mathrm{mIU} / \mathrm{ml})\end{array}$ & $\begin{array}{l}\mathbf{L H} \\
(\mathrm{mIU} / \mathrm{ml})\end{array}$ & $\begin{array}{l}\text { Testosterone } \\
(\mathrm{ng} / \mathrm{ml})\end{array}$ & $\begin{array}{l}\text { Progesterone } \\
(\mathrm{ng} / \mathrm{ml})\end{array}$ \\
\hline Distilled water (Control) & $2.06 \pm 0.06^{\mathrm{a}}$ & $1.73 \pm 0.06^{\mathrm{a}}$ & $0.97 \pm 0.04^{\mathrm{a}}$ & $6.80 \pm 0.69^{a}$ \\
\hline OV - treated & $2.42 \pm 0.16^{b}$ & $0.50 \pm 0.06^{b}$ & $1.21 \pm 0.08^{\mathrm{e}}$ & $7.24 \pm 0.54^{\mathrm{a}}$ \\
\hline $\begin{array}{l}\mathrm{OV}+2.4 \mathrm{mg} / \mathrm{kg} \text { bw of } \\
\text { metformin }\end{array}$ & $2.12 \pm 0.06^{\mathrm{a}}$ & $1.53 \pm 0.24^{\mathrm{e}}$ & $0.81 \pm 0.06^{b}$ & $6.61 \pm 0.17^{\mathrm{a}}$ \\
\hline $\begin{array}{l}\mathrm{OV}+10 \mathrm{mg} / \mathrm{kg} \text { bw of } V \text {. } \\
\text { album }\end{array}$ & $2.42 \pm 0.16^{b}$ & $0.50 \pm 0.06^{b}$ & $1.33 \pm 0.02^{\mathrm{d}}$ & $6.36 \pm 0.46^{a}$ \\
\hline $\begin{array}{l}\mathrm{OV}+50 \mathrm{mg} / \mathrm{kg} \text { bw of } V \text {. } \\
\text { album }\end{array}$ & $2.48 \pm 0.06^{b}$ & $1.24 \pm 0.26^{d}$ & $0.85 \pm 0.01^{\mathrm{c}}$ & $7.56 \pm 0.47^{\mathrm{a}}$ \\
\hline $\begin{array}{l}\mathrm{OV}+100 \mathrm{mg} / \mathrm{kg} \text { bw of } V \text {. } \\
\text { album }\end{array}$ & $2.24 \pm 0.08^{\mathrm{a}}$ & $1.14 \pm 0.05^{\mathrm{d}}$ & $1.05 \pm 0.05^{\mathrm{d}}$ & $6.22 \pm 0.25^{\mathrm{a}}$ \\
\hline $\begin{array}{l}\mathrm{OV}+200 \mathrm{mg} / \mathrm{kg} \text { bw of } V \text {. } \\
\text { album }\end{array}$ & $2.38 \pm 0.16^{\mathrm{b}}$ & $0.79 \pm 0.09$ & $1.01 \pm 0.02^{\mathrm{d}}$ & $6.58 \pm 0.44^{\mathrm{a}}$ \\
\hline
\end{tabular}

Values are mean \pm SEM for five determinations. Mean Values down the group with different superscript letters are significantly different $(\mathrm{p}<0.05)$ for each parameter, FSH: Follicle stimulating hormone, LH: Luteinizing hormone, OV: Oestradiol valerate, bw: Body weight.

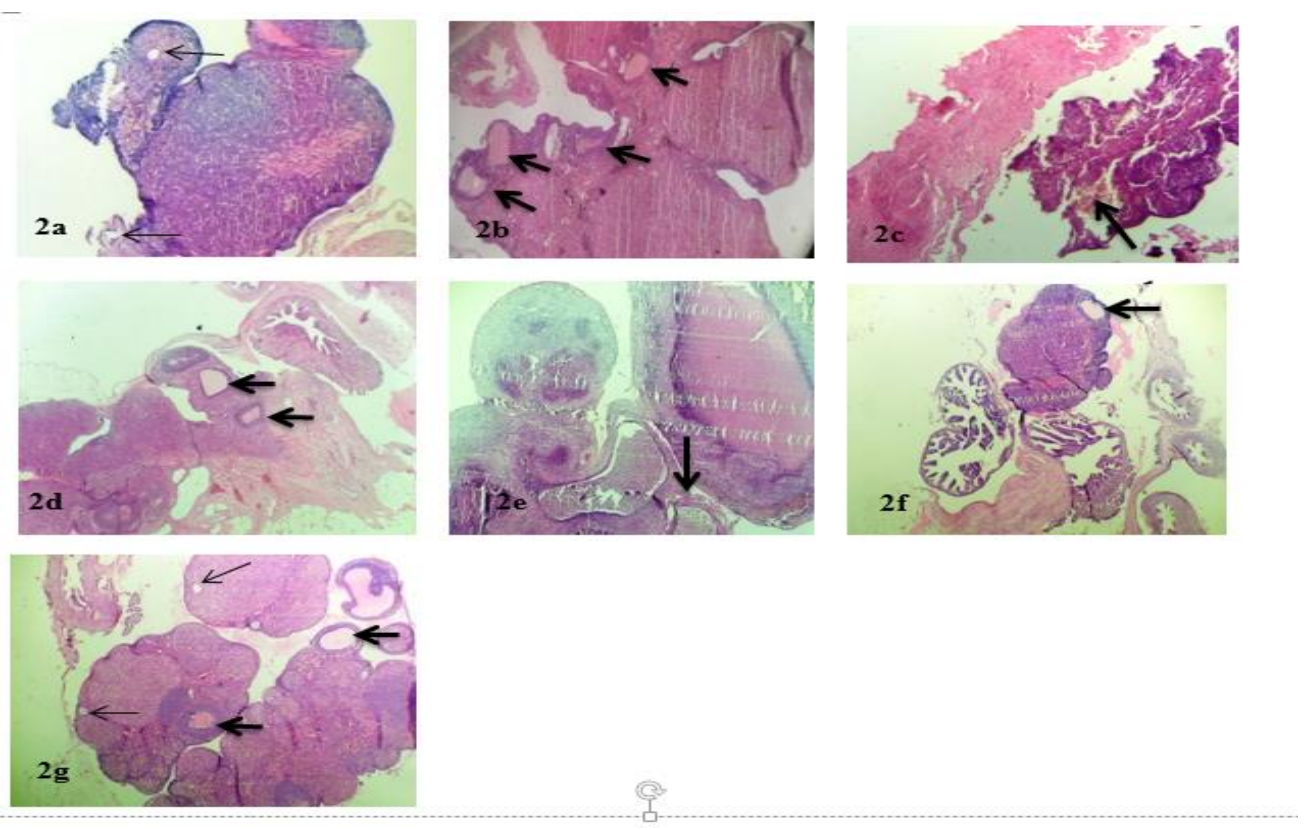

Figure 2: Photomicrograph of the ovaries following administration of aqueous extract of V. album leaves at different concentrations (X40, $\mathrm{H} \& \mathrm{E}$ stain).

Figure 2a: Distilled water-treated control rat; Figure 2b: $2 \mathrm{mg} / \mathrm{kg}$ body weight of oestradiol valerate-treated; Figure 2c: $2.4 \mathrm{mg} / \mathrm{kg}$ body weight of metformin; Figure 2d: $10 \mathrm{mg} / \mathrm{kg}$ body weight of $V$. album; Figure 2e: 50 $\mathrm{mg} / \mathrm{kg}$ body weight of $V$. album; Figure 2f: $100 \mathrm{mg} / \mathrm{kg}$ body weight of $V$. album; Figure $2 \mathrm{~g}: 200 \mathrm{mg} / \mathrm{kg}$ body weight of $V$. album./

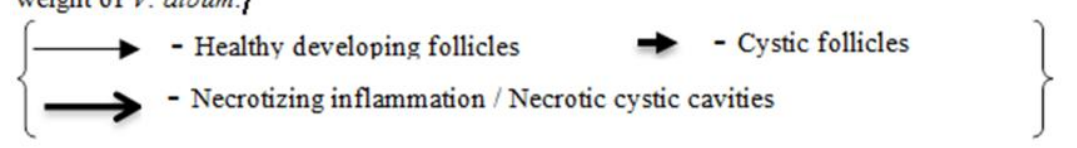




\section{DISCUSSION}

Pharmacological actions of medicinal plants are attributed to inherent chemical constituents that include primary metabolites such as mineral elements, as well as secondary metabolites like flavonoids, phenolics, glycosides, alkaloids and tannins which are found in the plants (Justin et al., 2014). Therefore, profiling the chemical constituents of $V$. album plant may provide an insight to its usefulness in PCOS condition (Chirchir et al., 2018) and the presence of detectable quantities of these metabolites in the plant may be responsible for the observed restorative and/or ameliorative effect of the medicinal plant on the chemically induced PCOS in the female rats For instance, saponins have been reported to possess hypoglycemic effect (Zheng et al., 2012), while tannins have been shown to have reproductive effects (Souza et al., 2006). Hypertension is a long-term risk associated with polycystic ovarian syndrome (Heibashy et al., 2013) and potassium supplementation has been found to lower blood pressure and ameliorate other cardiovascular diseases (Alicia and Mien, 2012). Chromium has also been reported to potentiate insulin action and improve glucose metabolism (Burtis and Ashwood 2001). Active form of chromium, $\mathrm{Cr}^{+3}$ (the low molecular weight chromium binding substrate (LMWCr) and/or chromium polynicotinate supplementation have been implicated in activation of insulin receptor tyrosine kinase activity there by improving insulin sensitivity in PCOS individual that presents with insulin resistance (Goodarzi et al., 2011).

Polycystic ovarian syndrome (PCOS) is diagnosed by the presence of at least two out of the clinical and/or biochemical characteristics which include hyperandrogenaemia (free testosterone being most sensitive), menstrual disorders manifesting as oligomenorrhea, amenorrhea or hypermenorrhea associated with anovulatory infertility and polycystic ovary (Rotterdam
ESHR/ ASRM, 2004). In the present study, PCOS was confirmed using the oestrous cycle, serum reproductive hormones (follicle stimulating hormone (FSH), luteinizing hormone (LH), testosterone and progesterone) and polycystic ovarian morphology after induction with oetradiol valerate; a synthetic variant of the oestradiol-17 $\beta$ (oestrogen). The consequence increased level of oestrogen causes thickening of the uterine lining and increased testosterone synthesis in the early follicular phase results in abnormal folliculeneogenesis (Alex et al., 2011). This is associated with disturbance in the duration of the sexual cycles and physiological inconsistency (Westwood, 2008).

Oestrous (sexual) cycle in rats occurs at every $4-5$ days and it is completed in four sequential phases called the proestrus, estrus, metestrus and diestrus phases. Each phase is characterized by high proportion of any of the three types of cells (epithelial cell, cornified cell and the leukocytes) found on the epithelial lining of genital tract of female rat (Westwood, 2008; Paccola et al., 2013). In the present study, the presence of the oestrus cell in the vaginal smears of the oestradiol valerate-treated rats that consisted of cornified cells alone may be an indication of persistent estrus phase (vaginal cornification). This suggests extra day of the oestrus phase with subsequent lengthening of the oestrous cycle from the normal 4 -5 days to 6-7 days. It could also imply lengthening of the previous oestrous cycle leading to delay in the next cycle. Such alteration in the oestrous cycle was attenuated by the administration of 50 , 100 and $200 \mathrm{mg} / \mathrm{kg}$ body weight of the extract as reflected by predominant leukocyte cells (diestrus phase) this was consistent with cells in the smears of the metformin- treated rats and the report of Yakubu and Ibiyo (2013) on prolongation of oestrous cycle from the normal $4-5$ days to 9-10 days in letrozole induced PCOS female rats.

Follicle stimulating hormone (FSH) and the luteinizing hormone (LH) are released 
in a pulsatile manner to stimulate development and maturity of one of the follicles in the ovary (Haggstrom, 2014). The persistent elevated follicle stimulating hormone in induced PCOS rats may be a reflection of disturbance in the hypothalamus - pituitary - gonadal axis balance, with resultant inappropriate stimulation of the ovaries and consequent production of multiple follicles in the ovaries. It might also be indication of oestradiol valerate-mediated positive feedback effect. The decrease in FSH by 10,100 and $200 \mathrm{mg} / \mathrm{kg}$ body weight of the extract suggest that certain component(s) of the extract may be responsible for the correction of the disturbances in the hypothalamus - pituitary - gonadal axis. This is supported by (Zangeneh et al., 2010) who suggested that flavonoids play an important role in the regulation of hypothalamus pituitary - gonadal axis release.

Luteinizing hormone released in a pulsatile manner, exert direct effects on the ovary which subsequently stimulate the secretion of the sex hormones, progesterone and androgen (s) which are converted to oestradiol by cytochrome $\mathrm{P}_{450} 19 \beta$ - aromatase in a cyclic manner that subsequently predicts ovulation (Haggstrom, 2014). Persistent high level of oestradiol in the circulation and resultant decrease in LH level may also account for continuous follicular development that manifest as polycystic ovaries. Mid cycle decreases in FSH with corresp onding LH surge is required to induce ovulation (Kadir et al., 2010; Haggstrom, 2014). The increase in the mid cycle LH after administration of 10 , 50 and $100 \mathrm{mg} / \mathrm{kg}$ body weight of the extract to the oestradiol valerate-treated rats suggest that the extract may restore abnormality in the hypothalamus- pituitary gonadal axis resulting in normal ovulation and regulation of oestrus cycle. This was also reported Yakubu and Ibiyo (2013).

Increase in serum testosterone level of the oestradiol valerate-treated rats may indicate that the aromatization of the androgens (testosterone and/or androsterondione) to oestrogens by the Cytochrome P450 19ß-aromatase might have been impaired causing accumulation of testosterone in the serum (Yakubu and Ibiyo, 2013). The decrease in testosterone level by the 50,100 and $200 \mathrm{mg} / \mathrm{kg}$ body weight of the extract could be attributed to some of the flavonoid constituents like quercetin and apiginin which have been shown to regulate steroidogenesis (Manthey et al., 2002; Li et al., 2011). The flavonoid may play an antioxidant role by enhancing the expression of genes responsible for synthesis of antioxidant enzymes and peptides (Vari et al., 2011; Gordon, 2012) or promote synthesis of sex hormone binding globulin (SHBG), the protein which binds some of the free testosterone thereby decreasing the concentration of circulating testosterone. It is also possible that some other constituents, such as calcium, might have activated the activity of aromatase.

The absence of alteration in serum progesterone of the oestradiol valerate-treated animals and all doses of extract, as well as metformin could imply that the clinical effect of PCOS progression with respect to this biomarker could not be established.

The atretic cystic follicles on the ovary of the induced PCOS rats is a clinical manifestation of defective follicleneogenesis leading to arrest of follicular growth and possible enhancement of production of ovarian nerve growth factor in the theca cell of the ovary (Lara et al., 2000) Furthermore, in the follicular phase of the sexual cycle, increased FSH release is required to drive the development of secondary follicles which, in the absence of adequate mid cycle LH surge, leads to maturation being arrested and the follicles becoming atretic (cystic) with disruption of oestrous cycle (Allan et al., 2006). Therefore, the atretic (cystic) follicles in the ovary of the oestradiol-treated rats and the consistent irregular cycles further emphasize the imbalance between FSH and 
LH release, leading to the arrest of follicular growth and maturation. The decrease in the number of the cystic follicles with normal architecture of the oviduct following administration of 10,100 and $200 \mathrm{mg} / \mathrm{kg}$ body weight aqueous extract of Viscum album leaves may imply ameliorative effect by certain constituents of the extract like Zinc, Selenium and flavonoids which have been shown to regulate folliculogenesis and oocyte maturation (Agawal et al., 2006). The necrotic cystic cavity at $50 \mathrm{mg} / \mathrm{kg}$ body weight of the extract which was similar to the necrotizing inflammation in the metformin-treated rats may be an indication of healing and recorvery of follicles (Jadhav et al., 2013).

\section{Conclusion}

Presence of saponins, flavonoids, phenolics, cardiac glycosides, $\mathrm{K}, \mathrm{Cr}, \mathrm{Se}, \mathrm{Cu}$ and $\mathrm{Zn}$ in the aqueous extract of $V$. album leaves may be part of the mechanisms responsible for the therapeutic (ameliorative and restorative) effects of the plant on polycystic ovarian syndrome which might have conferred on it the ability to restore abnormal biochemical and ovarian histopathological changes in the chemically induced PCOS rats, observed in this study.

\section{COMPETING INTERESTS}

The authors declare that there is no competing interest.

\section{AUTHORS' CONTRIBUTIONS}

FAO played a major role in designing, analysing and writing up this manuscript. AKS took part in the design, analysis, and write-up of the manuscript. NBA-B took part in the design, analysis, and write-up of the manuscript. EAB took part in the design, analysis, and supervised the write-up of the manuscript.

\section{ACKNOWLEDGMENTS}

The authors appreciated the professional assistance provided by Dr. O.O
Olaofe of Department of Histopathology, Ladoke Akintola University of Technology, Ogbomoso, Nigeria for his effort on the histological examination of the specimen. We also wish to appreciate Prof. P.B Olaitan of Department of Surgery, Ladoke Akintola University of Technology, Ogbomoso for reviewing the manuscript at various stages of its compilation.

\section{REFERENCES}

Agarwal A, Gupta S, Suresh S. 2006. Role of free radicals and antioxidants in Reproduction. Current Opinion in Obstetrics and Gynaecology, 18: 325 332.

Alex R, Ragini S, Sultan C, Eric W. 2011. Polycystic ovarian syndrome. Nature Reviews and Endocrinology, 7(4): 21931.

Alicia AM, Mien TXN. 2012. How does potassium supplementation lower blood pressure? America Journal of Physiology-Renal Physiology, 302(9): F1224-F1225. DOI: https//doi.org/101152/ajprenal.00429.2 011.

Allan CM, Wang Y, Jimenez M, Marshan B, Spaliviero J, Illingworth $\mathrm{P}$, Handelsman DJ. 2006. Follicle stimulating hormone increases primordial follicle reserve in mature female hypogonadal mice. Journal of Endocrinology, 188: 549-557. DOI: http://www.endocrj.org/10.1677/joe.1.06614

Burtis CA, Ashwood ER. 2001. Tietz fundamentals of Clinical Chemistry $\left(5^{\text {th }}\right.$ edn). W.B. Saunders Company: London.

Chirchir KD, Cheplogo PK, Omolo JO, Langata MK. 2018. Chemical constituents of Solanum mauense (Solanaceae) and Dovyalis abyssinica (Salicaceae). International Journal of Biological and Chemical Sciences, 12(2): 999-1007. DOI: 
http://dx.doi.org/

10.4314/ijbcs.v12i2.29

Chukwuma SE, Chigozie ME. 2016. Quqlitative and quantitative determination of phytochemical contents of indigenous Nigeria soft woods. New Journal of Science, ID5601327.

DOI: http:/dx.doi.org/10.1155/2016/5601327

Dumesic DA, Oberfield SE, StenerVictorin E, Narshall JC, Laven JS, Legro RS. 2015. Scientific statement on the diagnostic criteria, epidemiology, pathophysiology and molecular genetics of PCOS. Endocrine Reviews, 36(5): 487-525. DOI: https://doi.org/10.1210/er.2015-1018

Fernandez H, Morin-surruca M, Torre A, Faivre E, Deffieuz X, Gervaise A. 2011. Ovarian drilling for surgical treatment of PCOS. Comprehensive Review. Reproductive Biomedicine Online, 22(6): 556-568. DOI: 10.1016/J.rbmo.2011.03.013

Goodarzi MO, Dumesic DA, C hazenbalk G, Azziz R. 2011. Polycystic ovarysyndrome: Etiology, pathogenesis and diagnosis. Nature Reviews Endocrinology, 7: 219-231. DOI: 10:3038nrendo.2010.217

Haggstrom M. 2014. Reference range for oestradiol, progesterone, LH and FSH hormones during menstrual cycle. Wiver Journal of Medicine, 1(1):1-5. DOI: 10.15347 /wjm/2014.001

Heibashy MIA, Mazen GMA, Shahim MT. 2013. Metabolic changes and hormonal disturbances in PCOS rats and the amelioration effects of metformin and or cinnamon extract. Journal of American Society, 9(12): 54-62.

Ihegboro GO, Ebuehi OAT. 2014. Phytochemical investigation and the effects of aqueous plant extracts of viscum album on antioxidant property and biochemical profile as a measure of its therapeutic value. International Journal of Science and Research, 3(8) : 1192-1195.

Justin NK, Edmond L, Ally RM, Xin H. 20014. Plant secondary metabolites: Biosynthesis, classification, function and pharmacological properties. Journal of Pharmacy and Pharmacology, 2: 377-392.

Kadir RE, Omotoso GO, Enaibe BU, Caxton-Martins EA. 2011. Some Effects of Cyperus articulatus on the pituitary and gonadotropic hormones in adult female Wistar Rats. Asian Journal of Experimental and Biological Science, 2(3): 462-46.

Lara HE, Dissen GA, Leyton V, Parees A, Fuenzalida H, Fiedler, JL, Ojeda SR 2000. An increased intraovarian synthesis of nerve growth factor and its low affinity receptor is a principal component of steroid-induced polycystic ovary in rats. Endocrinology, 141:1059-1072.

DOI: 10:1210/en.1413.1059

Li W, Pandey AK, Yin X, Chen JJ, Stocco DM, Grammas P, Wang X. 2011. Effects of apigenin on steroidogenesis and steroidogenic acute regulatory gene expression in mouse lydig cells. Journal of Nutritional Biochemistry, 22(3): 212-218.

DOI: 10.1016/j.jnutbio.2010.01.004

Lipska KJ, Bailey CJ, Inzucchi SE. 2011. "Use of metformin in the setting of mild to moderate renal insufficiency". Diabetes Care, 34(6): 1431-7. DOI: 102337/dc10-2361

Manthey JA, Micheal EB, Bela SB. 2002. Flavonoids in cell function. In Advances in Experimental Medicine and Biology Book Series $\left(2002^{\text {nd }}\right.$ ed). Springer publisher; 505: 1-7.

Marcondes FK, Blanchi FJ, Tanno AP. 2002. Determination of the oestrous cycle Phases of rats: some helpful 
considerations. Brazilian Journal of Biology, 62: 609-614. DOI: 10.1590/S151969842002000400008

Michael HR, Wojciech P. 2016. Histology: a Text and Atlas: with Correlated Cell and Molecular Biology $\left(6^{\text {th }}\right.$ edn). Wolters Kluwer.

Min HC, Sun HL, Hey OK, Kim S, Hwa C, Jin Y. 2012. Comparism of assisted reproduction technology outcomes in infertile women with PCOS: in-vitro maturation, gonadotropin realizing hormone $(\mathrm{GnRH})$ agonist and $\mathrm{GnRH}$ antagonist cycles. Clinical Experimental Medicine, 39(4): 166171. DOI: $10.5653 / \mathrm{cem} .2012 .39 .4 .166$

Ofem OE, Eno AE, Imoru J, Nkanu E, Unoh F, Ibu JO. 2007. Effects of crude aqueous extracts of Viscum album (mistletoe) in hypertensive rats. Indian Journal of Pharmacology, 39(1): 1519. DOI: $10.4314 /$ phmedj.vli3.38879

Paccola CC, Pesende CG, Stumpp T, Migraglia SM, Cipri AI. 2013. The rat estrous cycle revisited: a quantitative and qualitative analysis. Animal Reproduction, 10(4): 677-683. DOI: https://www.researchgate.net/publicati on/285879458

Paixao L, Ramos BR, Lavarda A, Morsh MD, Spritzer MP. 2017. Animal models of hyperandrogenism and ovarian morphology changes as features of PCOS: A systematic review. Reproductive Biology and Endocrinology, 15:12. DOI: https://doi.org/10.1186/s12958-0170231-z

Pantel S. 2016. Plant derived cardiac glycosides; Role in heart ailments and cancer management. Biomedicine and pharmacotherapies, 84: 1036-1041. DOI: 10.1016/j.biopha.2016.10.030

Park JH, Kim YN, Kim JK, Park HY, Song BS. 2019. Viscothionin purified from mistletoe (Viscum album var.coloratum Ohwi) induces insulin secretion from pancreatic cells. Journal of Ethnopharmacol., 234: 172-179. DOI: 10.1016/j.jep.2019.01.014

Ray DK, Nayak PK, Rqutray TR, Vijayan V, Jena S. 2004. Elemental analysis of Antidiabetic medicinal plants using energy dispersive $\mathrm{x}$-ray fluorescence technique. Indian Journal of Physics, 78B: 103-105.

Rotterdam ESHRE/ASRM-Sponsored PCOS Consensus Workshop Group. 2004. Revised 2003 consensus on diagnostic criteria and long-term health risks related to polycystic ovary syndrome. Fertile Sterile, 81(1): 19-25. DOI: 10.1016/j.fertnstert.2003.10.004

Souza SM, Aquino LC, Banderia MA, Nobre ME, Viana GS. 2006. Antiinflamatory and anti-ulcer properties of tannins from Myracrodruonurundeuva allemao (Anacardiaceae) in rodents. Phytotherapy Research, 21(3): 220 225. DOI: $10.1002 /$ ptr.2011

Swetha R, Ravi BV, Nalini KS. 2015. Serum lipoprotein and lipid profile in PCOS. Journal of Clinical Science Research, 4(1): 2-6. DOI: 1015380/2277-5706.JCSR.14007

Umoh UF, Ekpo BAJ, Bala DN,Udobang JA, Cocobassey M, Etim EI. 2011. Phytochemical and comparative antidiabetic studies of leaf extracts of Viscum album from different plant host. International Journal of Biological and Chemical Sciences, 5(4): $1448-1454 . \quad$ DOI: http://dx.doi.org/10.4314/ijbcs.v5i4.11

Vari R, D'Achivio M, Filesi C, Cartotenuto S, Scazzocchio B, Santangelo C, Giovannini C, Masella R. 2011. Protocatechuic acid induces antioxidant/detoxifying enzyme expression through $\mathrm{NK}$ - mediated $\mathrm{Nf}_{2}$ activation in murine macrophages. Journal of Nutritional Biochemistry, 22(5): 409-417. DOI: 10.1016j.jnutbio.2010.03.008 
Vicas SI, Rugina D, Socaciu C. 2012. Antioxidant Activity of European Mistletoe (Viscum album), Phytochemicals as NutraceuticalsGlobal Approaches to Their Role in Nutrition and Health. Dr Venketeshwer Rao Edition. Available from:http://www.intechopen.com/book s/phytochemicals-as-nutraceuticalsglobal-approaches-to-their-roleinnutrition-and-health/antioxidantactivity-of-mistletoe.

Westwood FR. 2008. The female rat reproductive cycle; a practical histology guide to staging. Toxicologic Pathology, 36: 375-384. DOI: https://doi.org/10.1177/019262330831 5665

Yakubu MT, Akanji MA, Oladiji AT, Olatinwo AO, Adesokan AA, Yakubu MO, Owoyele BV, Sunmonu TO, Ajao MS. 2008. Effect of Cnidoscolous aconitifolius (Miller) I.M. Johnston leaf extract on reproductive hormones of female rats. Iranian Journal of Reproductive Medicine, 6(3): 149-155.

Yakubu MT, Ibiyo BO. 2013. Effects of aqueous extract of Cnestis ferruginea (Vahl ex DC) root on the biochemical and clinical parameters of antrazoleinduced Polycystic ovarian syndrome rat model. Journal of Endocrinology and Reproduction, 17(2): 99-112. DOI: $10.18519 /$ jer/2013/v17/75630

Zangeneh FZ, Minace B, Amir ZA, Ahangarpour A. 2010. Effect of Chamomile extract on biochemical and clinical parameters in rat model of PCOS. Journal of Reproductive Infertility, 11(3): 169-174.

Zheng T, Shu G, Yang Z, Mo S, Zhao Y, Mei Z. 2012. Antidiabetic effect of total saponins from Entadaphaseoioides L. Merr. In type 2 diabetic rats. Journal of Ethnopharmacology, 139(3): 812 821. DOI: $10.1016 /$ j.jep.2011.12.025 